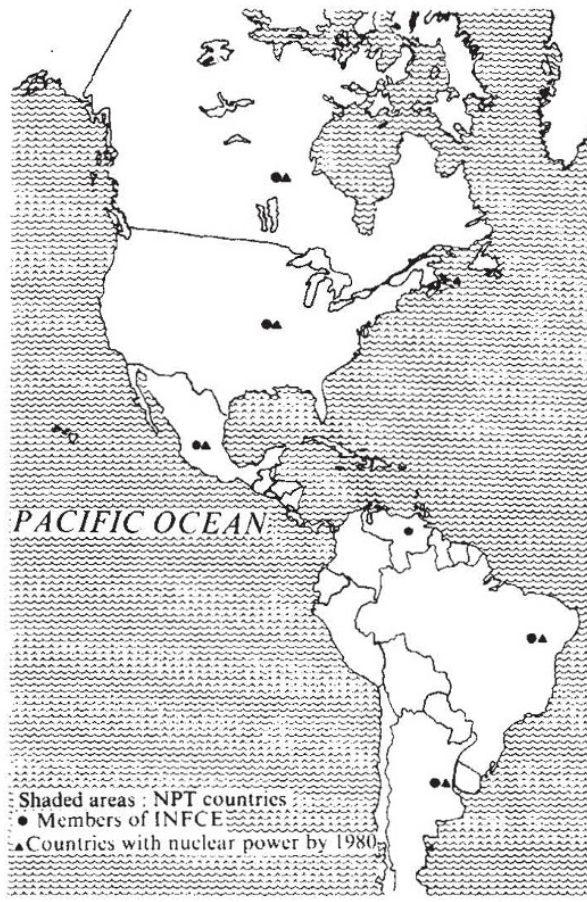

say capitulation - rather than risking the break-up of the coalition.

Why are the Commission's recommendations so different from what Fälldin hoped for? According to one of its Centre Party members, Birgitta Hambraes, the rot set in as soon as the experts were appointed. She says that, although all the members are agreed that Sweden will have to look to renewable energy sources for its long-term needs, the experts were chosen largely from areas concerned with present-day energy production. Expertise on nuclear power outweighed that on, for example, energy forests; and this is reflected in the recommendations. Mrs Hambraeus sees this as a problem of democracy: how to introduce the values a society wants to realise into a supposedly value-free examination of all possible courses of action open to that society? Because this was overlooked, she main tains, all the Commission's hard work has led to a report that is not in Sweden's interest at all.

The Centre Party's priorities are reflected in a government bill published this week, which proposed that $\mathrm{Sk} 1$ billion (about SUS217 million) be spent on energy research and development over the next three years. The allocations, on a scale about triple the ones for the current budget period, are oriented away from nuclear power (fission would get only about SUS3 million the first year, with undecided sums after that) to renewable energy sources: at least \$US45 million over the three years is proposed for wind, energy forests and peat.

The bill, which will be voted on before 1 July, outlines the three-year budget proposals for six areas:

- more efficient use of energy in industry (forestry, pulp, paper, iron and steel): \$US18.7 million

- transport (collective transport, alter- native fuels such as methanol, ethanol, synthetic petrol): \$US7 million

- building (insulation, solar heating, experimental buildings): \$US33.7 million - energy production (reducing dependence on imported oil through developing domestically-available $\quad-$ primarily renewable - energy sources such as wind, peat, energy forests; the technology of using coal; using hot water from industry for heating; safety aspects of fission energy; advanced energy sources such as fusion, solar and tidal power): \$US85.4 million

- studies of future energy production systems: \$US3 million

- basic research for carrying out these programmes: \$US6.5 million.

\$US5 million is proposed for international cooperation (the cost of Sweden's participation in the International Atomic Energy Agency, for example), and \$US20.8 million is kept in reserve for prototypes. A special allocation of \$US34 million is proposed for the stateowned Atomic Energy Company, which the government wants to re-name Studsvik Energy Technology Company to underline the fact that its expertise and resources will in future be used to research and develop all sorts of energy sources rather than primarily nuclear ones.

Presenting the bill, Energy Minister Olof Johansson explained that allocations to the various renewable energy sources had been proposed according to the timescale on which they were likely to produce resuolts. Thus wind energy, which the government expects could be developed and possibly put fully into operation during the 1980's, would be given SUS23 million; whereas solar energy (as distinct from solar heating), which is not expected to be operating before the turn of the century, would be allocated less than \$US10 million.
Wendy Barnaby

\section{Moves to terminate US fast breeder project may be illegal}

PRESIDENT Carter's efforts to terminate the controversial Clinch River fast breeder reactor project at Oak Ridge, Tennessee may be illegal, according to the US comptroller general, Mr Elmer B. Staats.

The president has consistently opposed the project, on the grounds that it could increase the chance of the proliferation of nuclear weapons, and claiming that it is "neither necessary to meet our projected energy requirements nor economically sound."

Last autumn he vetoed an appropriations bill which would have given money to continue the project. And last week, in signing a supplemental bill that included $\mathbf{\$} 80$ million for the Clinch River reactor, the president said that the money would be used to terminate the project.

However, Mr Staats, who is head of Congress' General Accounting Office, has written to both President Carter and the Energy Secretary, Dr James Schlesinger saying that this action is illegal.

According to Mr Staats, the legislation signed by Mr Carter required "that the funds available for the project be used only for the design, development, construction and operation of the liquid-metal fastbreeder reactor, and that they may not be used to terminate such activities."

In his letter, Mr Staats said that if the administration decided not to use the money for the purposes set out in the appropriations bill, the federal officials certifying termination of the project "shall be held accountable for and required to make good to the United States the amount of any payment prohibited by law."

David Dickson 